\title{
Optimal Sizing of Rooftop Rainwater Harvesting Tanks for Sustainable Domestic Water Use in the West Bank, Palestine
}

\author{
Sameer Shadeed *D and Sandy Alawna \\ Water and Environmental Studies Institute, An-Najah National University, Nablus P.O. Box 7, Palestine; \\ sandy-alawna@hotmail.com \\ * Correspondence: sshadeed@najah.edu
}

check for updates

Citation: Shadeed, S.; Alawna, S. Optimal Sizing of Rooftop Rainwater Harvesting Tanks for Sustainable Domestic Water Use in the West Bank, Palestine. Water 2021, 13, 573. https://doi.org/10.3390/w13040573

Academic Editor: Luís Filipe Sanches Fernandes

Received: 22 January 2021

Accepted: 7 February 2021

Published: 23 February 2021

Publisher's Note: MDPI stays neutral with regard to jurisdictional claims in published maps and institutional affiliations.

Copyright: (c) 2021 by the authors. Licensee MDPI, Basel, Switzerland. This article is an open access article distributed under the terms and conditions of the Creative Commons Attribution (CC BY) license (https:/ / creativecommons.org/licenses/by/ $4.0 /)$.
Abstract: In highly water-poor areas, rooftop rainwater harvesting (RRWH) can be used for a selfsustaining and self-reliant domestic water supply. The designing of an optimal RRWH storage tank is a key parameter to implement a reliable RRWH system. In this study, the optimal size of RRWH storage tanks in the different West Bank governorates was estimated based on monthly (all governorates) and daily (i.e., Nablus) inflow (RRWH) and outflow (domestic water demand, DWD) data. In the estimation of RRWH, five rooftop areas varying between $100 \mathrm{~m}^{2}$ and $300 \mathrm{~m}^{2}$ were selected. Moreover, the reliability of the adopting RRWH system in the different West Bank governorates was tested. Two-time series scenarios were assumed: Scenario 1, S1 (12 months, annual) and scenario 2, S2 (8 months, rainy). As a result, reliable curves for preliminary estimation of optimal RRWH storage tanks for the different West Bank governorates were obtained. Results show that the required storage tank for S1 (annual) is more than that of the S2 (rainy) one. The required storage tank to fulfill DWD is based on the average rooftop area of $150 \mathrm{~m}^{2}$, the average family members of 4.8 , and the average DWD of $90 \mathrm{~L}$ per capita per day $(\mathrm{L} / \mathrm{c} / \mathrm{d})$ varies between $\left(75 \mathrm{~m}^{3}\right.$ to $\left.136 \mathrm{~m}^{3}\right)$ and $\left(24 \mathrm{~m}^{3}\right.$ to $\left.84 \mathrm{~m}^{3}\right)$ for S2 for the different West Bank governorates. Further, it is found that the optimal RRWH tank size for the $150 \mathrm{~m}^{2}$ rooftop ranges between $20 \mathrm{~m}^{3}$ (in Jericho) to $75 \mathrm{~m}^{3}$ (in Salfit and Nablus) and between $20 \mathrm{~m}^{3}$ (in Jericho) to $51 \mathrm{~m}^{3}$ (in Jerusalem) for S1 and S2 scenarios, respectively. Finally, results show that the implementation of an RRWH system for a rooftop area of $150 \mathrm{~m}^{2}$ and family members of 4.8 is reliable for all of the West Bank governorates except Jericho. Whereas, the reliability doesn't exceed 19\% for the two scenarios. However, the reduction of DWDv is highly affecting the reliability of adopting RRWH systems in Jericho (the least rainfall governorate). For instance, a family DWDv of $3.2 \mathrm{~m}^{3} /$ month (25\% of the average family DWDv in the West Bank) will increase the reliability at a rooftop area of $150 \mathrm{~m}^{2}$ to $51 \%$ and $76 \%$ for S1 and S2, respectively.

Keywords: rooftop rainwater harvesting; optimal size; domestic water; water poverty; GIS; West Bank

\section{Introduction}

The misuse of different water resources has been leading to an increase of stress on these resources, thus impacting water availability, especially in arid and semi-arid regions [1]. This situation urges the necessity to look into more sustainable water resource options. For instance, rainwater harvesting $(\mathrm{RWH})$ is deemed to be a viable option to satisfy water needs for different purposes, among which, domestic use is the most important $[2,3]$.

Worldwide, domestic water needs represent about $10 \%$ of total water demand [4]. Thus, in arid and semi-arid areas, rooftop rainwater harvesting (RRWH) can be used as a sustainable option to overcome domestic water shortages [5-7]. RRWH is a simple technique for totally or partially satisfying domestic water demand (DWD) by collecting and storing rooftops rainwater [8]. The RRWH system consists of three main components; catchment area (rooftop), conveyance system, and storage tank [9].

In the West Bank, domestic water shortage is a dominant problem, where $57 \%$ of the total West Bank area is under high to very high domestic water poverty conditions [10]. 
However, domestic RWH is highly suitable in about $60 \%$ of the total West Bank area [10]. Moreover, the potential average annual RRWH volume in the high water-poor areas is about 32 million cubic meters (MCM) [11].

Potential RRWH volume (inflow) and DWD (outflow) are the key parameters in designing an optimal and reliable RRWH storage tank $[12,13]$. The storage tank is the most expensive component of an RRWH system [14]. However, the optimal RRWH storage tank is affected by several factors which include: Rainfall depth, rooftop area, availability of alternative water supply, water demand, and socio-economic constraints [9,15-18]. The estimation of an RRWH storage tank can be done by using a daily or monthly water balance approach [19]. To estimate an optimal RRWH tank size with an acceptable accuracy, a one-month time interval is commonly used [20]. In this study, the average monthly values of rainfall and DWD were used in the RRWH tank size estimation.

Given the monthly data of inflow and outflow, the optimal RRWH tank size can be estimated based on different methods. The empirical [17], stochastic parametric and nonparametric (or probabilistic analytical) [21,22], and continuous mass balance (e.g., Rippl) methods $[8,23]$. Empirical methods depend on developing empirical relations to describe the RRWH tank sizing. Stochastic methods were used to simulate important missing parameters in the tank size estimation of parametric and non-parametric approaches [24]. However, continuous simulation through the mass balance equation is the most popular approach used to estimate RRWH tank size [25].

The estimation of RRWH tank size can be accomplished based either on supply size or demand size, where supply size is the maximum volume of RRWH that can be harvested from a certain rooftop area. Demand size represents the maximum volume of water that is required to satisfy the water needs of a certain family during a specific period [26]. In this study, the mass balance between water supply (from RRWH) and demand (family water consumption) was conducted to estimate the required RRWH tank size. According to Rippl [27], the maximum cumulative positive differences between demand and supply represent the required RRWH tank size.

In the body of literature, there exist several studies that were focused on the estimation of optimal RRWH tank size. For instance, in Jordan [26,28], in Mexico [4], in Greece [19], in Northern Cyprus [29], in the north of Portugal [30], in Taiwan [13], in Iran [31], and in Australia [32,33].

This research aims to estimate optimal RRWH tank size for the different West Bank governorates based on a range of rooftop areas $\left(100 \mathrm{~m}^{2}\right.$ to $\left.300 \mathrm{~m}^{2}\right)$ and given the average DWD of $90 \mathrm{~L}$ per capita per day $(\mathrm{L} / \mathrm{c} / \mathrm{d})$ and average family members of 4.8 [34]. Two scenarios were tested; scenario 1 (S1), which is based on the annual rainfall (12 months), and scenario 2 (S2), which covers the rainy months from October to May (8 months).

The added value of this research is the development (for the first ever-time) of a reliable relation between rooftop areas and optimal RRWH tank size based on the average DWD in the West Bank. The novelty of this research can be summarized by the prediction of reliable RRWH storage tanks in the different West Bank governorates, which in turn can guide decision-makers toward sustainable utilization of potential RRWH, totally or partially, in Palestine. The applied approach can be used, mainly in arid and semi-arid areas, where water supply is uncertain and RRWH is deemed to be a robust domestic water supply.

\section{Materials and Methods}

\subsection{Study Area}

The study area is the West Bank with a total surface area of $5658 \mathrm{Km}^{2}$ [35]. Administratively, the West Bank is divided into 11 governorates; Salfit, Jenin, Tubas, Nablus, Jericho, Hebron, Tulkarm, Qalqiliya, Jerusalem, Bethlehem, and Ramallah and Al-Bireh (see Figure 1). However, the total population in the West Bank is nearly 2.88 million [36]. The surface elevation of the West Bank ranges between $410 \mathrm{~m}$ below mean sea level (msl) in the Dead Sea and $1022 \mathrm{~m}$ above (msl) in Tall Asur in Hebron [37]. Mediterranean climate 
is prevailing in the West Bank, which is characterized as hot and dry in summer and wet and cold in winter [37]. The West Bank rainy season usually extends over 8 months from October to May and most of the West Bank rainfalls $(80 \%)$ in winter (December to February) $[38,39]$. Moreover, the rainfall in the West Bank is characterized by high temporal and spatial variation. The long-term annual average varies between $133 \mathrm{~mm}$ in the proximity of the Jordan River (in Jericho) to $658 \mathrm{~mm}$ in the central mountains (in Salfit) with an annual average value of about $420 \mathrm{~mm}$ for the entire West Bank (see Figure 1).

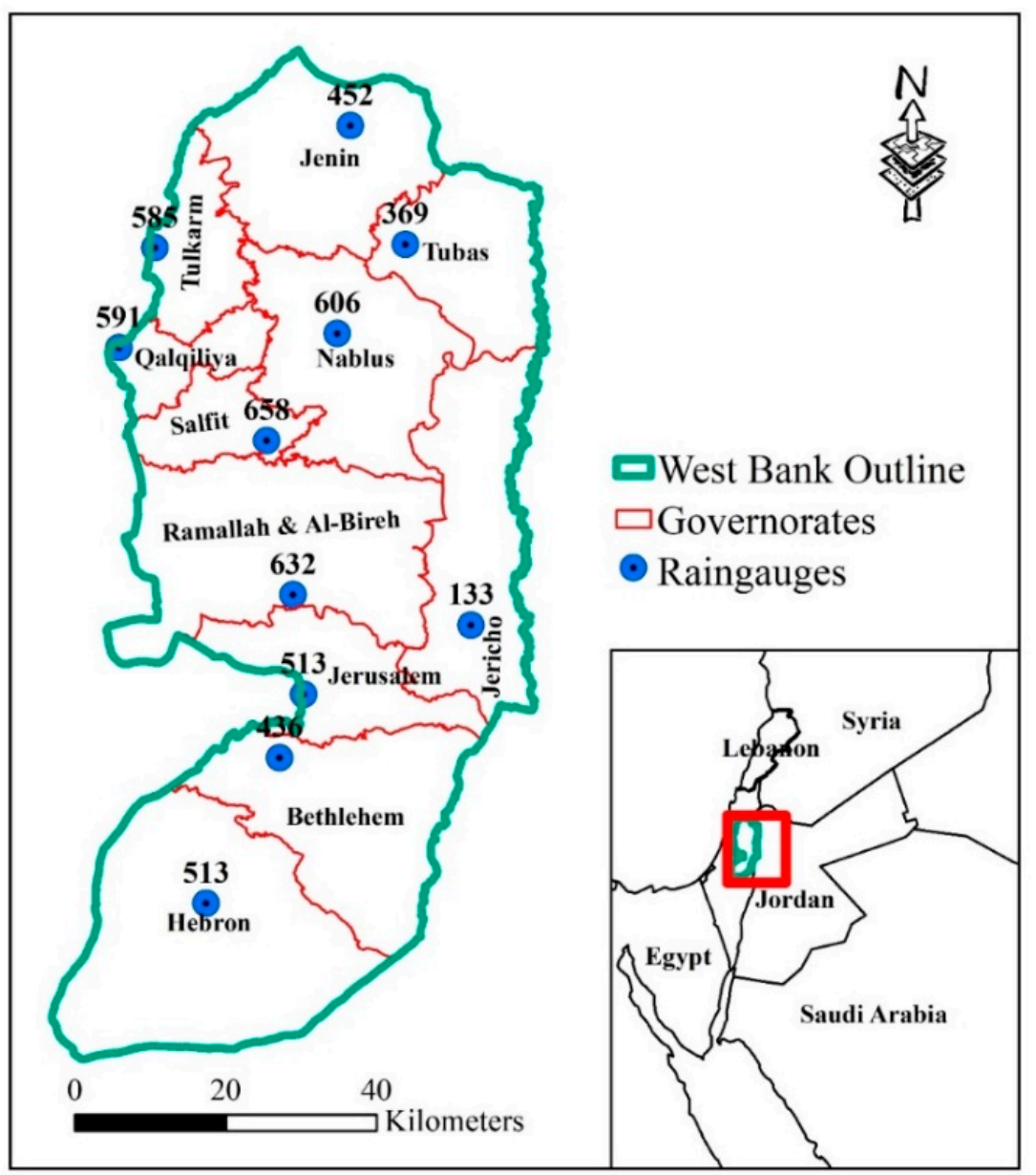

Figure 1. The regional location map of the West Bank together with the long-term annual average rainfall (in $\mathrm{mm}$ ).

The West Bank has been divided into four agro-climatic zones; sub-humid (22\%), semi-arid (44\%), arid (30\%), and hyper-arid (4\%) (see Figure 2) [40]. The land use map is classified into seven categories: Arable land (supporting grains), built-up areas, irrigated farming (supporting vegetables), Israeli settlements, permanent crops (grapes, olives, citrus, and other fruit trees), rough grazing/subsistence farming, and woodland/forest. In this research, the focus is on the built-up areas where rooftops account for about $28 \%$ that was considered in the estimation of RRWH volumes in the different governorates [35].

In the West Bank, water is being obtained either from groundwater wells and springs or purchased from an Israeli water company (Mekorot). According to the Palestinian water authority reports, the domestic water demand, consumption, and supply are $146 \mathrm{MCM}, 88$ MCM, and $119 \mathrm{MCM}$, respectively [34]. Accordingly, the domestic water supply-demand gap is nearly $27 \mathrm{MCM}$. In the West Bank, the average annual potential RRWH volume is estimated at 37 MCM [11]. Therefore, the proper implementation of RRWH can potentially bridge the increasing domestic water supply-demand gap in the West Bank. 


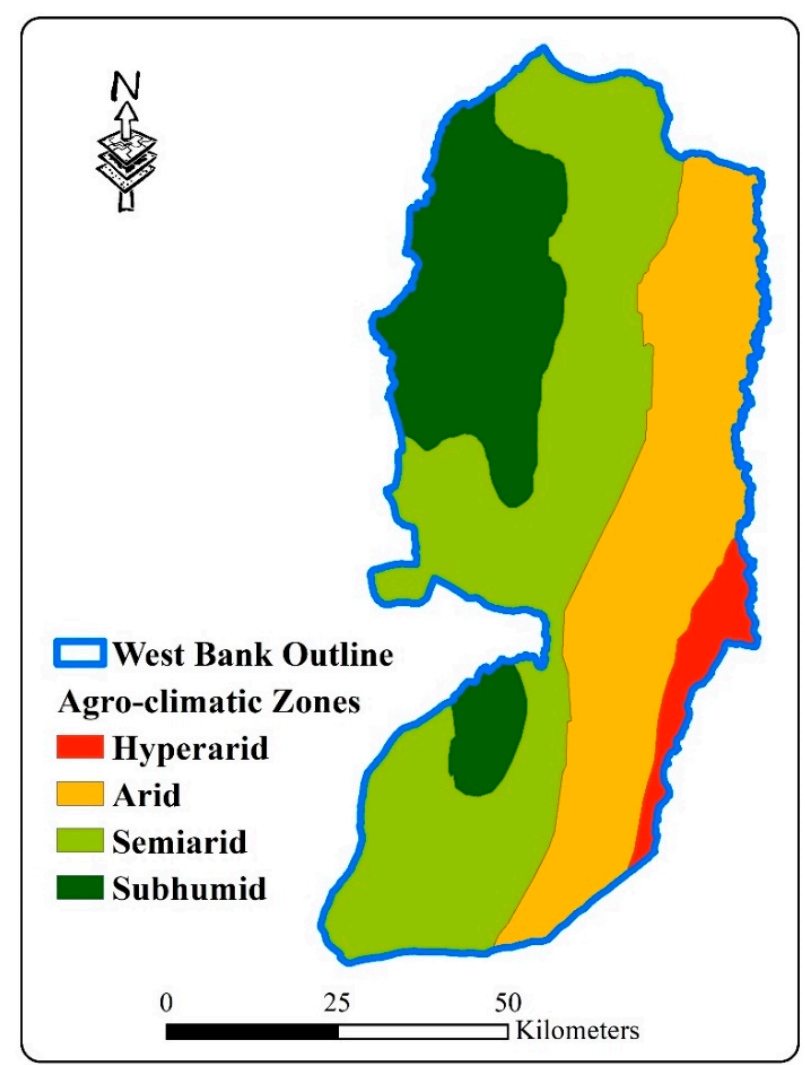

Figure 2. Agro-climatic zones in the West Bank.

\subsection{Methodology}

As mentioned earlier, there are different approaches to estimate the optimal RRWHo tank size. In this study, the required tank size (RRWHr) was estimated based on the continuous mass balance approach as presented by Rippl [27].

$$
\Delta S=\mathrm{RRWH}_{\mathrm{V}}-\mathrm{DWD}_{\mathrm{V}}
$$

where: $\Delta S$ is the change in storage, $\mathrm{RRWH}_{\mathrm{V}}$ is the potential (monthly / daily) inflow volume to the storage tank, and $\mathrm{DWD}_{\mathrm{V}}$ is the (monthly/daily) outflow volume from the storage tank.

In this study, two RRWH scenarios are assumed and assessed. These are the annual, 12 months (S1), and the rainy, 8 months (S2). In these scenarios, the monthly time step was used in the estimation of RRWHo. The rainfall all-over the hydrologic year from October to September and over the rainy months from October to May was assumed for S1 and S2, respectively. However, and due to the lack of daily rainfall data, S1 and S2 scenarios were only tested given the available daily rainfall records at Nablus. DWDv is estimated based on the average DWD of $90 \mathrm{~L} / \mathrm{c} / \mathrm{d}$ and average family members of 4.8 . As such, monthly $\mathrm{DWD}_{\mathrm{V}}$ of $13 \mathrm{~m}^{3}$ (for all governorates) and daily $\mathrm{DWD}_{\mathrm{V}}$ of $0.43 \mathrm{~m}^{3}$ (for Nablus) was used [34]. For S2, the estimated RRWHo tank size can be used to cover the DWD in the 8 rainy months. However, in the dry period from June to September, the tank can be utilized to store water from the municipal sources because, in most of the West Bank governorates, water is being supplied 2 days a week.

The RRWHV is estimated based on Equation (2) [41].

$$
\mathrm{RRWH}_{\mathrm{V}}=\mathrm{R} \times \mathrm{A} \times \mathrm{R}_{\mathrm{C}}
$$

where: $\mathrm{R}$ is the average monthly/daily rainfall depth, $\mathrm{A}$ is the rooftop area, and $\mathrm{R}_{\mathrm{C}}$ is the runoff coefficient. 
The average monthly (all governorates, Table 1) and daily (Nablus governorate, Table 2) rainfall data for some selected rainfall stations (presented in Figure 1) for the period (2013-2019) were obtained from the Palestinian Metrological Department [42].

Table 1. The average monthly rainfall (mm) in the different West Bank governorates for the period (2013-2019).

\begin{tabular}{|c|c|c|c|c|c|c|c|c|c|c|c|}
\hline Governorate & Jerusalem & Jenin & Tulkarm & Qalqiliya & $\underset{\text { Al-Bireh }}{\text { Ramallah \& }}$ & Nablus & Bethlehem & Hebron & Jericho & Salfit & Tubas \\
\hline Oct & 10 & 20 & 21 & 30 & 20 & 22 & 17 & 26 & 6 & 35 & 14 \\
\hline Nov & 60 & 46 & 59 & 67 & 68 & 49 & 67 & 47 & 20 & 68 & 36 \\
\hline Dec & 78 & 122 & 193 & 196 & 181 & 200 & 102 & 142 & 38 & 214 & 106 \\
\hline Jan & 111 & 125 & 135 & 128 & 123 & 154 & 131 & 138 & 32 & 149 & 101 \\
\hline Feb & 88 & 89 & 103 & 92 & 103 & 113 & 93 & 92 & 32 & 102 & 78 \\
\hline Mar & 51 & 40 & 47 & 49 & 59 & 51 & 56 & 52 & 15 & 63 & 33 \\
\hline Apr & 30 & 30 & 22 & 30 & 33 & 29 & 33 & 28 & 15 & 32 & 25 \\
\hline May & 6 & 7 & 6 & 5 & 7 & 6 & 6 & 6 & 6 & 5 & 8 \\
\hline Jun & 0 & 0 & 1 & 5 & 0 & 1 & 0 & 0 & 0 & 0 & 0 \\
\hline Jul & 0 & 0 & 0 & 0 & 0 & 0 & 0 & 0 & 0 & 0 & 0 \\
\hline Áug & 0 & 0 & 0 & 0 & 0 & 0 & 0 & 0 & 0 & 0 & 0 \\
\hline Sep & 2 & 1 & 0 & 1 & 1 & 0 & 1 & 2 & 0 & 1 & 0 \\
\hline
\end{tabular}

Table 2. Nablus daily rainfall for the period (2013-2019).

\begin{tabular}{cccc}
\hline Year & Sum $(\mathbf{m m})$ & MADR $* \mathbf{m m})$ & Number of Rainy Days (Rainfall $>\mathbf{1} \mathbf{~ m m})$ \\
\hline $2012 / 2013$ & 701 & 107 & 44 \\
$2013 / 2014$ & 466 & 123 & 24 \\
$2014 / 2015$ & 667 & 83 & 53 \\
$2015 / 2016$ & 498 & 48 & 42 \\
$2016 / 2017$ & 476 & 74 & 41 \\
$2017 / 2018$ & 566 & 61 & 42 \\
$2018 / 2019$ & 925 & 90 & 59 \\
\hline
\end{tabular}

MADR *: Maximum annual daily rainfall.

For the aforementioned scenarios, the RRWHr values were estimated based on the maximum cumulative sum of positive (monthly/daily) differences between DWDv and RRWHv. Whereas, the annual potential (maximum) tank size (RRWHm) is estimated based on the average annual rainfall values (2013-2019) of the selected rainfall stations at different governorates.

Moreover, rooftop areas of $100 \mathrm{~m}^{2}, 150 \mathrm{~m}^{2}, 200 \mathrm{~m}^{2}, 250 \mathrm{~m}^{2}$, and $300 \mathrm{~m}^{2}$ were used in the estimation of $R R W H_{V}$ values. $R_{C}$ of 0.8 was selected, which is in the range of $R_{C}$ values that appeared in the body of literature for the concrete rooftops [43-46]. RRWHo values for each governorate and the different rooftop areas are set as the minimum of either RRWHr or RRWHm values.

The reliability (Re) of adopting an RRWH system in the West Bank was tested based on Equation (3) [47].

$$
\mathrm{Re}=\mathrm{RRWH}_{\mathrm{V}} / \mathrm{DWD}_{\mathrm{V}}
$$

The overall methodological approach for this research is illustrated in Figure 3. 


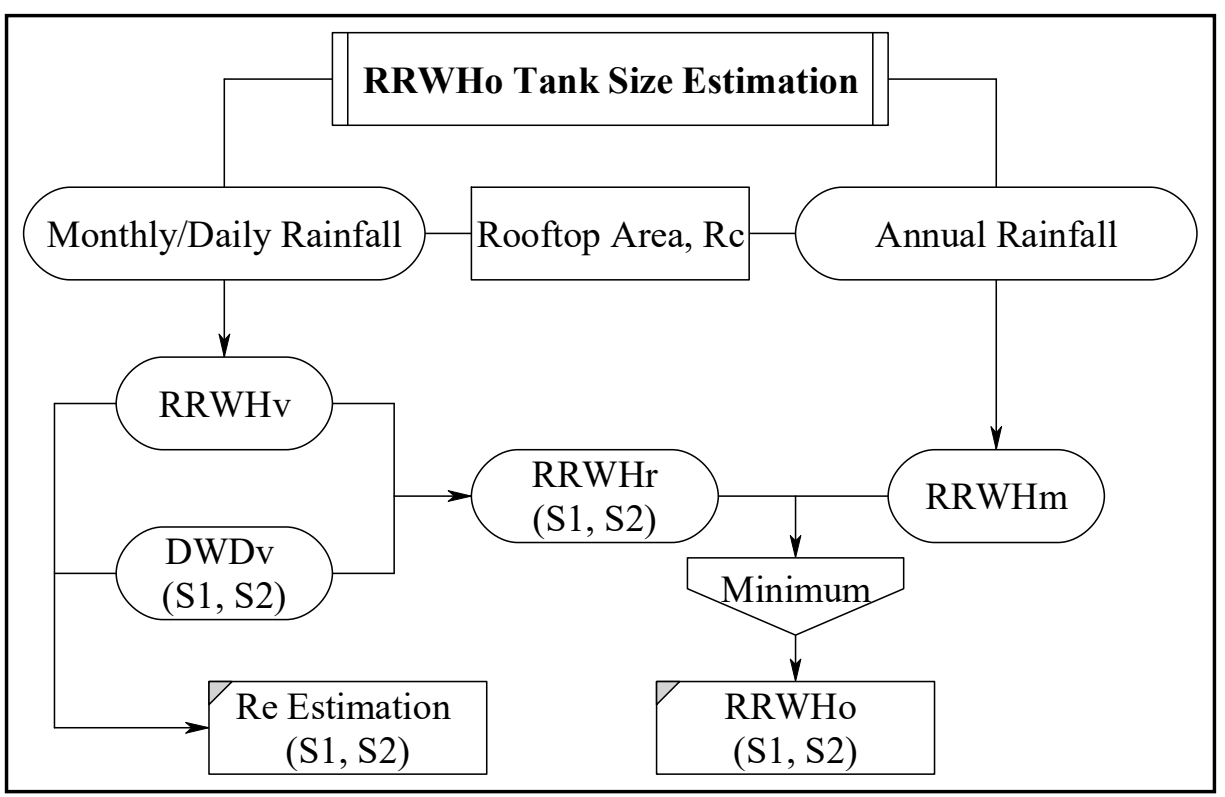

Figure 3. The overall methodological approach.

\section{Results and Discussion}

\subsection{RRWHo Tank Size Estimation}

Based on the available rainfall data and given the aforementioned approach, $\mathrm{RRWH}_{\mathrm{O}}$ values for the different governorates were estimated. For Nablus, as an example, and given the two scenarios, calculations of RRWHr, RRWHm, and RRWHo for the different rooftop areas are presented in Tables 3 and 4 for S1 and S2 scenarios, respectively. For all governorates, calculations of RRWHr, RRWHm, and RRWHo are presented in the Supplementary Materials.

From Tables 3 and 4, and to satisfy the DWD of $90 \mathrm{~L} / \mathrm{c} / \mathrm{d}$ for an average family size of 4.8 members, it is noticed that the RRWHr is inversely proportioned with the rooftop areas for the two scenarios, while the RRWHm is being increased as the rooftop area increased. For the $\mathrm{S} 1$ scenario and rooftop areas of $150 \mathrm{~m}^{2}$ and less, the RRWHo tank size is being controlled by the RRWHm. Whereas, for rooftop areas of $200 \mathrm{~m}^{2}$ and more, RRWHo tank size is being controlled by the RRWHr. For rooftop areas of less than $100 \mathrm{~m}^{2}$, the RRWHm represents the RRWHo, and for the rooftop areas of more than $150 \mathrm{~m}^{2}$, the RRWHo values are being controlled by the RRWHr values and for $\mathrm{S} 1$ and $\mathrm{S} 2$ scenarios.

Table 5 illustrates the RRWHo tank sizes for Nablus governorate for the two scenarios given the monthly and daily rainfall data. It is clear from the table that the RRWHo values obtained from both monthly and daily rainfall data are almost the same. This in turn supports the use of monthly rainfall data for the estimation of RRWHo tank size. 
Table 3. RRWHo calculations for Nablus governorate for the different rooftop areas for the S1 scenario.

\begin{tabular}{|c|c|c|c|c|c|c|c|c|c|c|c|c|c|c|c|c|c|c|c|c|c|}
\hline \multirow{3}{*}{ Month } & \multirow{3}{*}{$\begin{array}{l}\text { Rainfall } \\
\text { (mm) }\end{array}$} & \multicolumn{20}{|c|}{ Rooftop Area $\left(\mathrm{m}^{2}\right)$} \\
\hline & & \multicolumn{4}{|c|}{100} & \multicolumn{4}{|c|}{150} & \multicolumn{4}{|c|}{200} & \multicolumn{4}{|c|}{250} & \multicolumn{4}{|c|}{300} \\
\hline & & 1 & 2 & 3 & 4 & 1 & 2 & 3 & 4 & 1 & 2 & 3 & 4 & 1 & 2 & 3 & 4 & 1 & 2 & 3 & 4 \\
\hline Oct & 21.8 & 1.7 & 13.0 & 11.2 & 11.2 & 2.6 & 13.0 & 10.3 & 10.3 & 3.5 & 13.0 & 9.5 & 9.5 & 4.4 & 13.0 & 8.6 & 8.6 & 5.2 & 13.0 & 7.7 & 7.7 \\
\hline Nov & 49.4 & 4.0 & 13.0 & 9.0 & 20.2 & 5.9 & 13.0 & 7.0 & 17.4 & 7.9 & 13.0 & 5.1 & 14.5 & 9.9 & 13.0 & 3.1 & 11.7 & 11.9 & 13.0 & 1.1 & 8.8 \\
\hline Dec & 199.8 & 16.0 & 13.0 & -3.0 & 17.2 & 24.0 & 13.0 & -11.0 & 6.4 & 32.0 & 13.0 & -19.0 & -4.5 & 40.0 & 13.0 & -27.0 & -15.3 & 48.0 & 13.0 & -35.0 & -26.2 \\
\hline Jan & 154.1 & 12.3 & 13.0 & 0.6 & 17.8 & 18.5 & 13.0 & -5.5 & 0.8 & 24.7 & 13.0 & -11.7 & -16.2 & 30.8 & 13.0 & -17.9 & -33.2 & 37.0 & 13.0 & -24.0 & -50.2 \\
\hline Feb & 112.5 & 9.0 & 13.0 & 4.0 & 21.8 & 13.5 & 13.0 & -0.54 & 0.3 & 18.0 & 13.0 & -5.0 & -21.2 & 22.5 & 13.0 & -9.54 & -42.7 & 27.0 & 13.0 & -14.0 & -64.2 \\
\hline Mar & 51.0 & 4.1 & 13.0 & 8.9 & 30.7 & 6.1 & 13.0 & 6.8 & 7.1 & 8.2 & 13.0 & 4.8 & -16.4 & 10.2 & 13.0 & 2.8 & -40.0 & 12.2 & 13.0 & 0.7 & -63.5 \\
\hline May & 6.4 & 0.5 & 13.0 & 12.4 & 53.7 & 0.8 & 13.0 & 12.2 & 28.8 & 1.0 & 13.0 & 11.9 & 3.8 & 1.3 & 13.0 & 11.7 & -21.2 & 1.5 & 13.0 & 11.4 & -46.2 \\
\hline Jun & 0.6 & 0.0 & 13.0 & 12.9 & 66.6 & 0.1 & 13.0 & 12.9 & 41.7 & 0.1 & 13.0 & 12.9 & 16.7 & 0.1 & 13.0 & 12.8 & -8.3 & 0.1 & 13.0 & 12.8 & -33.3 \\
\hline Jul & 0.0 & 0.0 & 13.0 & 13.0 & 79.6 & 0.0 & 13.0 & 13.0 & 54.6 & 0.0 & 13.0 & 13.0 & 29.6 & 0.0 & 13.0 & 13.0 & 4.6 & 0.0 & 13.0 & 13.0 & -20.4 \\
\hline Aug & 0.0 & 0.0 & 13.0 & 13.0 & 92.6 & 0.0 & 13.0 & 13.0 & 67.6 & 0.0 & 13.0 & 13.0 & 42.6 & 0.0 & 13.0 & 13.0 & 17.6 & 0.0 & 13.0 & 13.0 & -7.4 \\
\hline Sep & 0.1 & 0.0 & 13.0 & 13.0 & 105.5 & 0.0 & 13.0 & 12.9 & 80.5 & 0.0 & 13.0 & 12.9 & 55.5 & 0.0 & 13.0 & 12.9 & 30.5 & 0.0 & 13.0 & 12.9 & 5.5 \\
\hline Annual & 625.0 & 50.0 & 155.5 & & & 75.0 & 155.5 & & & 100.0 & 155.5 & & & 125.0 & 155.5 & & & 150.0 & 155.5 & & \\
\hline \multicolumn{2}{|c|}{ RRWHr } & & & & 106 & & & & 81 & & & & 56 & & & & 31 & & & & 9 \\
\hline \multicolumn{2}{|c|}{ RRWHm } & & & & 50 & & & & 75 & & & & 100 & & & & 125 & & & & 150 \\
\hline \multicolumn{2}{|c|}{ RRWHo } & & & & 50 & & & & 75 & & & & 56 & & & & 31 & & & & 9 \\
\hline
\end{tabular}


Table 4. RRWHo calculations for Nablus governorate for the different rooftop areas for the S2 scenario.

\begin{tabular}{|c|c|c|c|c|c|c|c|c|c|c|c|c|c|c|c|c|c|c|c|c|c|}
\hline \multirow{3}{*}{ Month } & \multirow{3}{*}{$\begin{array}{c}\text { Rainfall } \\
(\mathrm{mm})\end{array}$} & \multicolumn{20}{|c|}{ Rooftop Area $\left(\mathrm{m}^{2}\right)$} \\
\hline & & \multicolumn{4}{|c|}{100} & \multicolumn{4}{|c|}{150} & \multicolumn{4}{|c|}{200} & \multicolumn{4}{|c|}{250} & \multicolumn{4}{|c|}{300} \\
\hline & & 1 & 2 & 3 & 4 & 1 & 2 & 3 & 4 & 1 & 2 & 3 & 4 & 1 & 2 & 3 & 4 & 1 & 2 & 3 & 4 \\
\hline Oct & 21.8 & 1.7 & 13.0 & 11.2 & 11.2 & 2.6 & 13.0 & 10.3 & 10.3 & 3.5 & 13.0 & 9.5 & 9.5 & 4.4 & 13.0 & 8.6 & 8.6 & 5.2 & 13.0 & 7.7 & 7.7 \\
\hline Nov & 49.4 & 4.0 & 13.0 & 9.0 & 20.2 & 5.9 & 13.0 & 7.0 & 17.4 & 7.9 & 13.0 & 5.1 & 14.5 & 9.9 & 13.0 & 3.1 & 11.7 & 11.9 & 13.0 & 1.1 & 8.8 \\
\hline Dec & 199.8 & 16.0 & 13.0 & -3.0 & 17.2 & 24.0 & 13.0 & -11.0 & 6.4 & 32.0 & 13.0 & -19.0 & -4.5 & 40.0 & 13.0 & -27.0 & -15.3 & 48.0 & 13.0 & -35.0 & -26.2 \\
\hline Jan & 154.1 & 12.3 & 13.0 & 0.6 & 17.8 & 18.5 & 13.0 & -5.5 & 0.8 & 24.7 & 13.0 & -11.7 & -16.2 & 30.8 & 13.0 & -17.9 & -33.2 & 37.0 & 13.0 & -24.0 & -50.2 \\
\hline Feb & 112.5 & 9.0 & 13.0 & 4.0 & 21.8 & 13.5 & 13.0 & -0.5 & 0.3 & 18.0 & 13.0 & -5.0 & -21.2 & 22.5 & 13.0 & -9.5 & -42.7 & 27.0 & 13.0 & -14.0 & -64.2 \\
\hline Mar & 51.0 & 4.1 & 13.0 & 8.9 & 30.7 & 6.1 & 13.0 & 6.8 & 7.1 & 8.2 & 13.0 & 4.8 & -16.4 & 10.2 & 13.0 & 2.8 & -40.0 & 12.2 & 13.0 & 0.7 & -63.5 \\
\hline May & 6.4 & 0.5 & 13.0 & 12.4 & 53.7 & 0.8 & 13.0 & 12.2 & 28.8 & 1.0 & 13.0 & 11.9 & 3.8 & 1.3 & 13.0 & 11.7 & -21.2 & 1.5 & 13.0 & 11.4 & -46.2 \\
\hline Annual & 624.3 & 49.9 & 103.7 & & & 74.9 & 103.7 & & & 99.9 & 103.7 & & & 124.9 & 103.7 & & & 149.8 & 103.7 & & \\
\hline \multicolumn{2}{|c|}{ RRWHr } & & & & 54 & & & & 29 & & & & 15 & & & & 12 & & & & 9 \\
\hline \multicolumn{2}{|c|}{ RRWHm } & & & & 50 & & & & 75 & & & & 100 & & & & 125 & & & & 150 \\
\hline \multicolumn{2}{|c|}{ RRWHo } & & & & 50 & & & & 29 & & & & 15 & & & & 12 & & & & 9 \\
\hline \multicolumn{2}{|c|}{ Rv (\%) } & & & & 48 & & & & 72 & & & & 96 & & & & 120 & & & & 145 \\
\hline
\end{tabular}


Table 5. Comparison between RRWHo values for Nablus governorate for the two scenarios and based on the monthly and daily rainfall data.

\begin{tabular}{|c|c|c|c|c|}
\hline \multirow{3}{*}{$\begin{array}{l}\text { Rooftop Areas } \\
\qquad\left(\mathrm{m}^{2}\right)\end{array}$} & \multicolumn{4}{|c|}{ RRWHo Tank Size $\left(\mathrm{m}^{3}\right)$} \\
\hline & \multicolumn{2}{|c|}{ S1 } & \multicolumn{2}{|c|}{$\mathrm{S} 2$} \\
\hline & Monthly & Daily & Monthly & Daily \\
\hline 100 & 50 & 49 & 50 & 49 \\
\hline 150 & 75 & 75 & 29 & 31 \\
\hline 200 & 56 & 59 & 15 & 15 \\
\hline 250 & 31 & 35 & 12 & 13 \\
\hline 300 & 9 & 10 & 9 & 11 \\
\hline
\end{tabular}

In Figure 4, the RRWHr for the two scenarios and the RRWHm versus rooftop areas for the different governorates are shown.
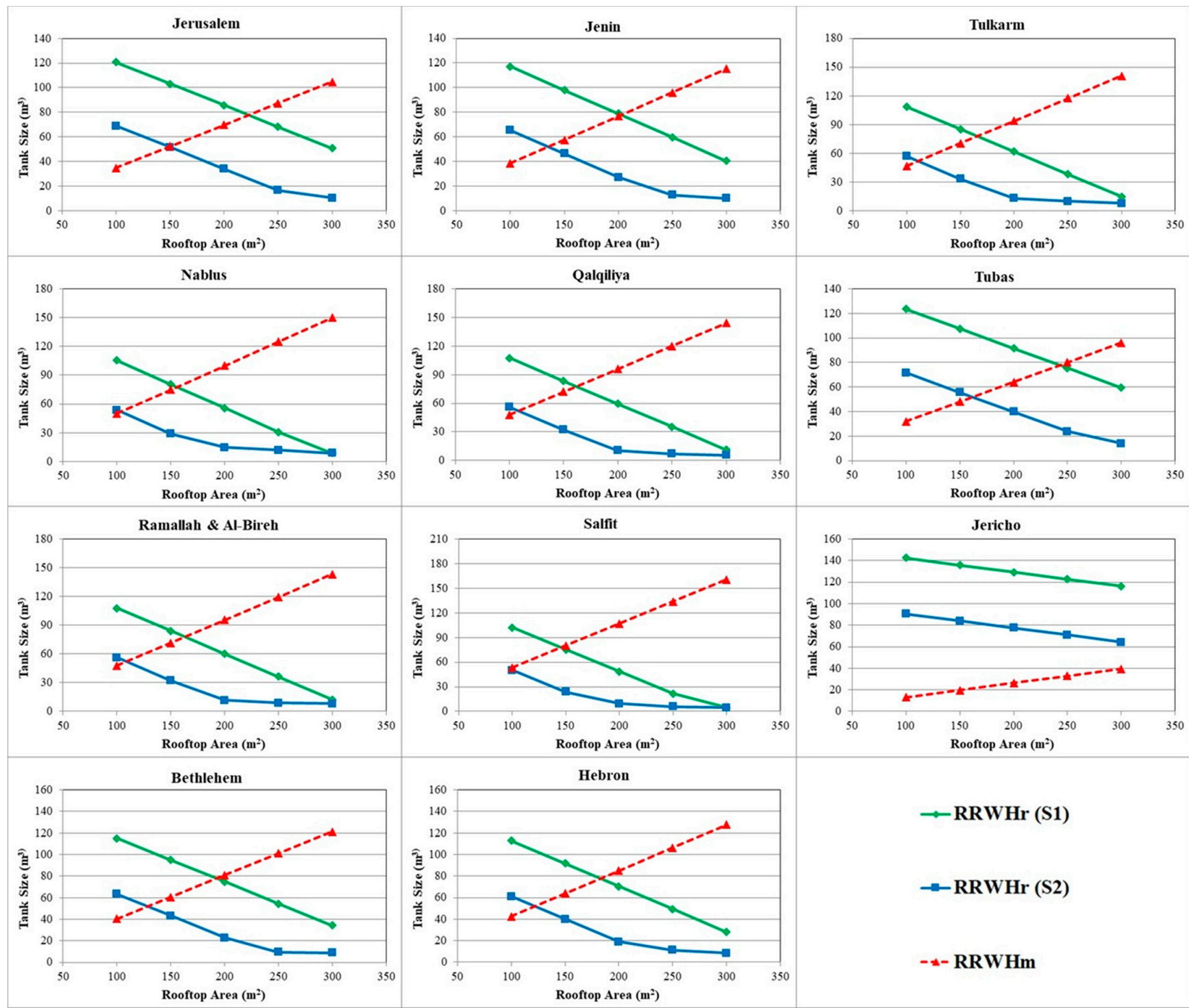

Figure 4. RRWHr and RRWHm versus different rooftop areas in the different governorates for S1 and S2 scenarios.

From Figure 4, it is noticed that the RRWHo values for S1 (annual) are more than the RRWHo values for S2 (rainy). This can be attributed to the highly cumulative differences between $\mathrm{DWD}_{\mathrm{V}}$ and $\mathrm{RRWH}_{\mathrm{V}}$. For the S1 scenario, in the governorates of Tulkarm, Nablus, 
Qalqiliya, Hebron, and Ramallah and Al-Bireh, the RRWHr tank size exceeds the RRWHm tank size for the rooftop areas of less than $150 \mathrm{~m}^{2}$ (RRWHo equals RRWHm). However, RRWHr tank sizes are less than the RRWHm tank size in Jenin and Bethlehem for the rooftop areas of more than $200 \mathrm{~m}^{2}$ (RRWHo equals RRWHr).

In governorates of Nablus, Qalqiliya, Salfit, and Ramallah and Al-Bireh, the RRWHr values are controlling the RRWHo tank sizes for the S2 scenario and rooftop areas of more than $100 \mathrm{~m}^{2}$. In Jericho (the least rainfall governorate), the RRWHm are dominating the selection of RRWHo tank sizes for S1 and S2 scenarios and the different rooftop areas. That means satisfying DWD in Jericho is not feasible by adopting the RRWH techniques either for annual (12 months) or rainy (8 months).

For the average rooftop area of $150 \mathrm{~m}^{2}$, the spatial variation of RRWHo tank sizes for the different governorates for S1 and S2 are presented in Figure 5. From the figure, it is clear that the minimum value of RRWHo $\left(20 \mathrm{~m}^{3}\right.$, in Jericho) and for S1 and S2 scenarios. Whereas, the maximum value of RRWHo $\left(75 \mathrm{~m}^{3}\right.$, in Salfit and Nablus) and $\left(51 \mathrm{~m}^{3}\right.$, in Jerusalem) for S1 and S2 scenarios, respectively.

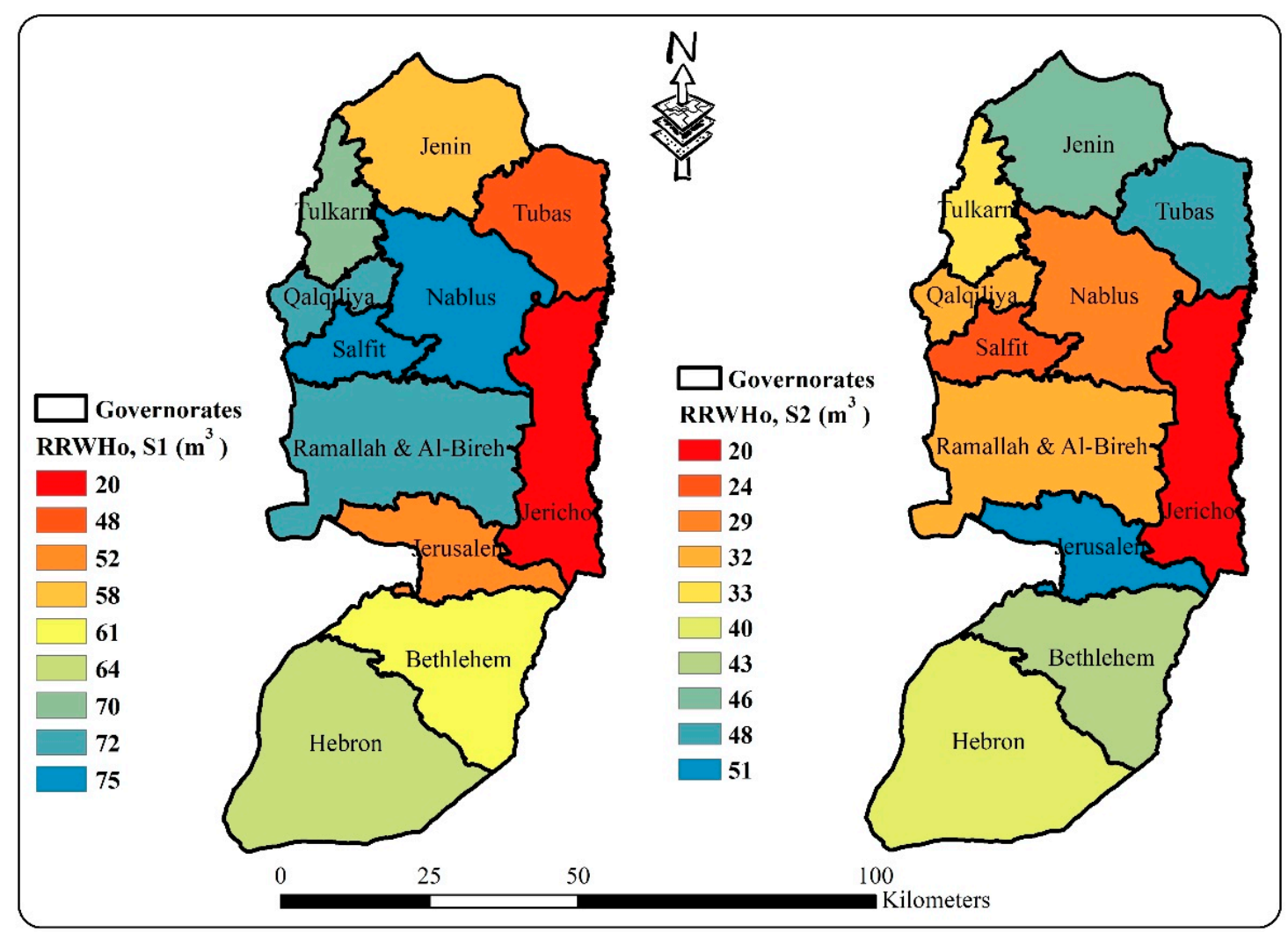

Figure 5. RRWHo tank size for a rooftop area of $150 \mathrm{~m}^{2}$ for the different West Bank governorates and the S1 and S2 scenarios.

\subsection{Reliability of RRWH}

In this research, the reliability (Re) of adopting RRWH was tested for S1 and S2 scenarios at the different rooftop areas $\left(100 \mathrm{~m}^{2}, 150 \mathrm{~m}^{2}, 200 \mathrm{~m}^{2}, 250 \mathrm{~m}^{2}\right.$, and $\left.300 \mathrm{~m}^{2}\right)$ and average monthly DWDv ( $13 \mathrm{~m}^{3} /$ family).

Figure 6 presents the variation of Re for the S1 and S2 and different rooftop areas. Generally, the Re values increase as the rooftop area increases. This can be attributed to the increased values of the estimated $\mathrm{RRWH}_{\mathrm{V}}$. It is also noticed that for a rooftop area of $150 \mathrm{~m}^{2}$, the maximum value of Re is in Salfit governorate and the minimum one in Jericho for both scenarios. Accordingly, Re in Salfit is $52 \%$ and $77 \%$ for S1 and S2, respectively. While in Jericho, Re equals 13\% for S1 and 19\% for S2. 


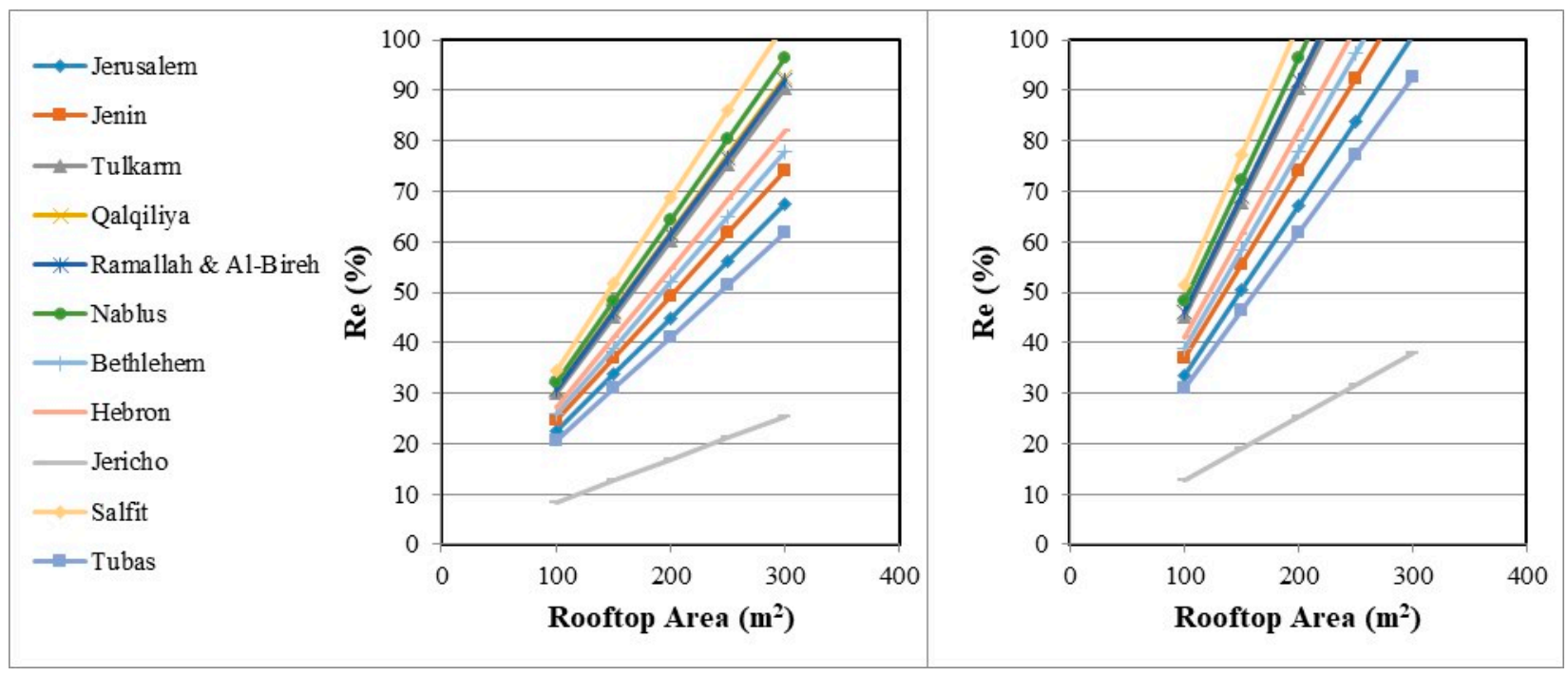

Figure 6. Re percentages of different West Bank governorates for the different rooftop areas for a monthly DWDv of $13 \mathrm{~m}^{3}$ / family. S1 (left); S2 (right).

Moreover, the Re was tested for a monthly $\mathrm{DWD}_{\mathrm{V}}$ of $6.5 \mathrm{~m}^{3} /$ family $(50 \%$ of the average DWD in the West Bank) at the different rooftop areas (see Figure 7). From the figure, generally, Re increased as DWD decreased. For example, at a rooftop area of $150 \mathrm{~m}^{2}$, the Re values for Salfit increased to nearly $100 \%$ for S1 and S2. Meanwhile, in Jericho (the least reliable governorate), Re increased from $13 \%$ to $25 \%$ for S1 and from $19 \%$ to $38 \%$ for S2. Additionally, the Re of adopting RRWH increased to more than $80 \%$ for the rooftop areas of $200 \mathrm{~m}^{2}$ and more for all of the West Bank governorates except for Jericho. Therefore, to assess the effect of reducing DWD on the reliability of adopting an RRWH system in Jericho, family DWD $\mathrm{V}_{\mathrm{V}}$ values of $3.2,1.3$, and $1 \mathrm{~m}^{3} /$ month, which represent $25 \%, 10 \%$, and $8 \%$ from the average family DWDv in the West Bank $\left(13 \mathrm{~m}^{3} / \mathrm{month}\right)$, respectively (see Table 6). From the table, Re of $100 \%$ can be obtained at rooftop areas of $100 \mathrm{~m}^{2}$ and more if DWDv decreased to $8 \%$ and $10 \%$ for the S1 and S2 scenarios, respectively. At a $150 \mathrm{~m}^{2}$ rooftop area, Re values approach $100 \%$ for a family DWDv of $1.3 \mathrm{~m}^{3} /$ month $(10 \%$ of the average $\mathrm{DWD}_{\mathrm{V}}$ ) for both $\mathrm{S} 1$ and $\mathrm{S} 2$ scenarios.

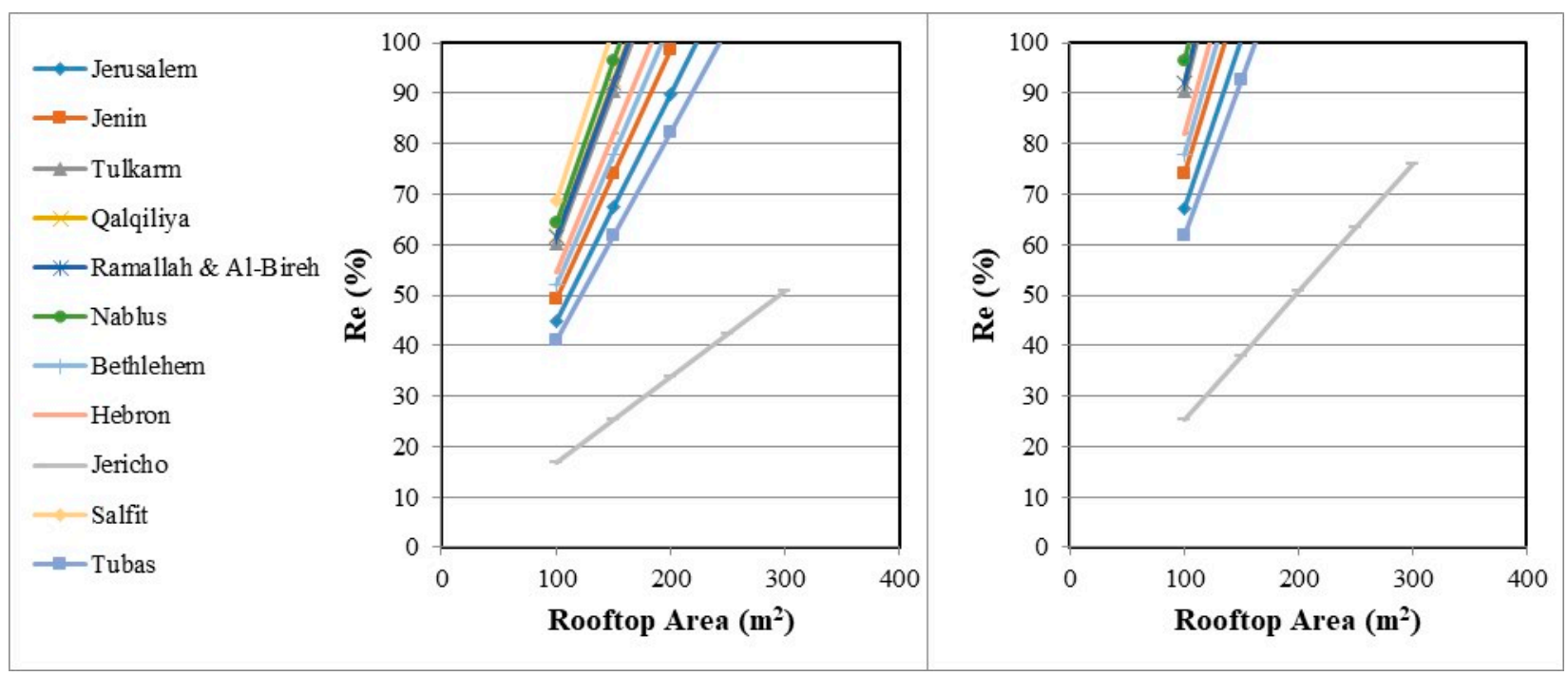

Figure 7. Re percentages of different West Bank governorates for the different rooftop areas for a monthly DWDv of $6.5 \mathrm{~m}^{3}$ /family. S1 (left); S2 (right). 
Table 6. Re values for selected $\mathrm{DWD}_{\mathrm{V}}$ values (percentages from the average $\mathrm{DWD}_{\mathrm{V}}$ ) in Jericho governorate.

\begin{tabular}{ccccccc}
\hline & \multicolumn{5}{c}{$\operatorname{Re}(\mathbf{\%})$} \\
Rooftop Areas $\left(\mathbf{m}^{\mathbf{2}}\right)$ & $\mathbf{2 5 \%}$ & $\mathbf{1 0 \%}$ & $\mathbf{8 \%}$ & $\mathbf{2 5 \%}$ & $\mathbf{1 0 \%}$ & $\mathbf{8 \%}$ \\
\hline 100 & 34 & 85 & - & 51 & - & - \\
150 & 51 & - & - & 76 & - & - \\
200 & 68 & - & - & - & - & - \\
250 & 85 & - & - & - & - & - \\
300 & - & - & - & - & - & - \\
\hline "-" Re values more than $99 \%$. & & & &
\end{tabular}

\section{Conclusions}

This paper presents a realistic estimation of RRWHo tank size in the West Bank based on the continuous mass balance (Rippl) approach. Moreover, the reliability of the implementation of RRWH techniques in the different governorates was also tested. The estimation of RRWHo tank size was accomplished based on the average monthly DWDv of $13 \mathrm{~m}^{3}$ / family and based on two scenarios (S1, annual, and S2, rainy). For the average rooftop area $\left(150 \mathrm{~m}^{2}\right)$, results indicate that the maximum RRWHo tank size $\left(75 \mathrm{~m}^{3}\right)$ is in Salfit and Nablus and $51 \mathrm{~m}^{3}$ in Jerusalem for S1 and S2, respectively. The minimum one is in Jericho $\left(20 \mathrm{~m}^{3}\right)$ for both scenarios. Reliability results show that the implementation of RRWH techniques is mostly reliable ( $\mathrm{S} 1, \mathrm{Re}=52 \%$ and $\mathrm{S} 2, \mathrm{Re}=77 \%$ ) in Salfit to satisfy the average DWD of $90 \mathrm{~L} / \mathrm{c} / \mathrm{d}$ at a rooftop area of $150 \mathrm{~m}^{2}$ and a family size of 4.8 members. The reliability of adopting RRWH is inversely proportional to the decrease of DWDv. Moreover, in Jericho governorate (rainfall is the least in the West Bank, $133 \mathrm{~mm} /$ year), Re of about $100 \%$ can be achieved at a rooftop area of $150 \mathrm{~m}^{2}$ and a reduction of a family $\mathrm{DWD}$ to $10 \%$ $\left(1.3 \mathrm{~m}^{3} /\right.$ month $)$ for S1 and S2 scenarios.

The developed RRWHr tank size curves for the different West Bank governorates will help different stakeholders in the designing of optimal RRWH storage tanks for the different rooftop areas to fulfill domestic water needs, totally or partially. Whereas, the reliability assessment will guide decision-makers toward sustainable implementation of RRWH techniques in the different West Bank governorates for the different rooftop areas. Finally, further research is recommended to incorporate social and economic factors for designing optimal RRWH storage tanks to promote the utilization of RRWH for a selfsustaining and self-reliant water supply in Palestine.

Supplementary Materials: The following are available online at https:/ / www.mdpi.com/2073-444 $1 / 13 / 4 / 573 /$ s1.

Author Contributions: Conceptualization, S.S.; methodology, S.S. and S.A.; GIS, S.A., and S.S.; formal analysis, S.S.; writing - original draft preparation, S.A.; writing-review and editing of the final version, S.S.; project administration, S.S. All authors have read and agreed to the published version of the manuscript.

Funding: This research was performed within the framework of the Palestinian Dutch Academic Cooperation Program on Water (PADUCO 2), funded by the Netherlands Representative Office (NRO) in Ramallah, Palestine. The financial support is gratefully acknowledged.

Institutional Review Board Statement: Not applicable.

Informed Consent Statement: Not applicable.

Data Availability Statement: The data presented in this study are available in the Supplementary Materials.

Conflicts of Interest: The authors declare no conflict of interest. 


\section{References}

1. EEA. EEA Signals 2009: Key Environmental Issues Facing Europe; European Environment Agency: Copenhagen, Denmark, 2009.

2. Santos, C.; Taveira-Pinto, F. Analysis of different criteria to size rainwater storage tanks using detailed methods. Resour. Conserv. Recycl. 2013, 71, 1-6. [CrossRef]

3. Shadeed, S.; Lange, J. Rainwater harvesting to alleviate water scarcity in dry conditions: A case study in Faria Catchment, Palestine. Water Sci. Eng. 2010, 3, 132-143.

4. Bocanegra-Martínez, A.; Ponce-Ortega, J.M.; Nápoles-Rivera, F.; Serna-González, M.; Castro-Montoya, A.J.; El-Halwagi, M.M. Optimal design of rainwater collecting systems for domestic use into a residential development. Resour. Conserv. Recycl. 2014, 84, 44-56. [CrossRef]

5. Awawdeh, M.; Al-Shraideh, S.; Al-Qudah, K.; Jaradat, R. Rainwater harvesting assessment for a small size urban area in Jordan. Int. J. Water Resour. Environ. Eng. 2012, 4, 415-422.

6. Mays, L.; Antoniou, G.P.; Angelakis, A.N. History of water cisterns: Legacies and lessons. Water 2013, 5, 1916-1940. [CrossRef]

7. Ndiritu, J.G.; McCarthy, S.; Tshirangwana, N. Probabilistic assessment of the rainwater harvesting potential of schools in South Africa. Proc. Int. Assoc. Hydrol. Sci. 2014, 364, 435-440. [CrossRef]

8. Fewkes, A. Modeling the performance of rainwater collection systems: Towards a generalized approach. Urban. Water 2000, 1, 323-333. [CrossRef]

9. MwengeKahinda, J.; Taigbenu, A.E.; Boroto, J.R. Domestic rainwater harvesting to improve water supply in rural South Africa. Phys. Chem. Earth 2007, 32, 1050-1057. [CrossRef]

10. Shadeed, S.; Judeh, T.; Almasri, M. Developing a GIS-based water poverty and rainwater harvesting suitability maps for domestic use in the Dead Sea region (West Bank, Palestine). Hydrol. Earth Syst. Sci. 2019, 23, 1581-1592. [CrossRef]

11. Alawna, S. Rooftop Rainwater Harvesting to Alleviate Domestic Water Shortage in the West Bank, Palestine. Master's Thesis, An-Najah National University, Nablus, Palestine, 2019.

12. Khastagir, A.; Jayasuriya, N. Parameters influencing the selection of optimal rainwater tank size: A case study for Melbourne. In Proceedings of the Rain Water and Urban Design Conference, Sydney, Australia, 21-23 August 2007.

13. Liaw, C.; Chiang, Y. Dimensionless Analysis for Designing Domestic Rainwater Harvesting Systems at the Regional Level in Northern Taiwan. Water 2014, 6, 3913-3933. [CrossRef]

14. Sturm, M.; Zimmermann, M.; Schutz, K.; Urban, W.; Hartung, H. Rainwater harvesting as an alternative water resource in rural sites in central northern Namibia. Phys. Chem. Earth 2009, 34, 776-785. [CrossRef]

15. Aladenola, O.O.; Adeboye, O.B. Assessing the potential for rainwater harvesting. Water Resour. Manag. 2010, $24,2129-2137$. [CrossRef]

16. Eroksuz, E.; Rahman, A. Rainwater tanks in multi-unit buildings: A case study for three Australian cities. Resour. Conserv. Recycl. 2010, 54, 1449-1452. [CrossRef]

17. Ghisi, E. Parameters influencing the sizing of rainwater tanks for use in houses. Water Resour. Manag. 2010, 24, 2381-2403. [CrossRef]

18. Palla, A.; Gnecco, I.; Lanza, L.G.; La Barbera, P. Performance analysis of domestic rainwater harvesting systems under various European climate zones. Resour. Conserv. Recycl. 2012, 62, 71-80. [CrossRef]

19. Londra, P.; Theocharis, A.; Baltas, E.; Tsihrintzis, V. Optimal sizing of rainwater harvesting tanks for domestic use in Greece. Water Resour. Manag. 2015, 29, 4357-4377. [CrossRef]

20. Treiber, B.; Schultz, G. Comparison of required reservoir storages computed by the Thomas-Fiering model and the Karlsruhe Model Type A and B. Hydrol. Sci. J. 1976, 21, 177-185. [CrossRef]

21. Basinger, M.; Montalto, F.; Lall, U. Rainwater harvesting system reliability model based on non-parametric stochastic rainfall generator. J. Hydrol. 2010, 392, 105-118. [CrossRef]

22. Cowden, J.R.; Watkins, D.W.; Mihelcic, J.R. Stochastic rainfall modeling in West Africa: Parsimonious approaches for domestic rainwater harvesting assessment. J. Hydrol. 2008, 361, 64-77. [CrossRef]

23. Campisano, A.; Modica, C. Optimal sizing of storage tanks for domestic rainwater harvesting in Sicily. Resour. Conserv. Recycl. 2012, 63, 9-16. [CrossRef]

24. Semaan, M.; Day, S.D.; Garvi, M.; Ramakrishnan, N.; Pearce, A. Optimal sizing of rainwater harvesting systems for domestic water usages: A systematic literature review. Resour. Conserv. Recycl. 2020, 6, 100033. [CrossRef]

25. Imteaz, M.A.; Ahsan, A.; Naser, J.; Rahman, A. Reliability analysis of rainwater tanks in Melbourne using daily water balance model. Resour. Conserv. Recycl. 2011, 56, 80-86. [CrossRef]

26. Abu-Zreig, M.; Ababneh, F.; Abdullah, F. Assessment of rooftop rainwater harvesting in northern Jordan. Phys. Chem. Earth 2019, 114, 102794. [CrossRef]

27. Rippl, W. The Capacity of storage-reservoirs for water-supply. Min. Proc. Inst. Civ. Eng. 1883, 71, $270-278$.

28. Abu-Zreig, M.; Hazayme, A.; Shatanawi, M. Evaluation of residential rainfall harvesting systems in Jordan. Urban Water J. 2012, 10, 1-7. [CrossRef]

29. Okoye, C.O.; Solyal, O.; Akıntu, B. Optimal sizing of storage tanks in domestic rainwater harvesting systems: A linear programming approach. Resour. Conserv. Recycl. 2015, 104, 131-140. [CrossRef]

30. Matos, C.; Santos, C.; Pereira, S.; Bentes, I.; Imteaz, M. Rainwater storage tank sizing: Case study of a commercial building. Int. J. Sustain. Built Environ. 2013, 2, 109-118. [CrossRef] 
31. Komeh, Z.; Memarian, H.; Tajbakhsh, S. Reservoir volume optimization and performance evaluation of rooftop catchment systems in arid regions: A case study of Birjand, Iran. Water Sci. Eng. 2017, 10, 125-133. [CrossRef]

32. Rahman, A.; Keane, J.; Imteaz, M.A. Rainwater harvesting in Greater Sydney: Water savings, reliability and economic benefits. Resour. Conserv. Recycl. 2012, 61, 16-21. [CrossRef]

33. Imteaz, M.A.; Shanableh, A.; Rahman, A.; Ahsan, A. Optimisation of rainwater tank design from large roofs: A case study in Melbourne, Australia. Resour. Conserv. Recycl. 2011, 55, 1022-1029. [CrossRef]

34. PCBC. Water Supply-Demand Statistics. Available online: http://www.pcbs.gov.ps/Portals/_Rainbow/Documents/water-A9-2 018.html (accessed on 10 December 2020).

35. Ministry of Local Governance. GeoMOLG. Available online: https://geomolg-geomolgarconline.hub.arcgis.com/search? collection=Dataset (accessed on 4 February 2019).

36. PCBS. Final Result of Population, Housing, and Establishment Census; Palestinian Central Bureau of Statistics: Ramallah, Palestine, 2017.

37. UNEP. Desk Study on the Environment in the Occupied Palestinian Territories; United Nation Environment Programme: Nairobi, Kenya, 2003.

38. Shadeed, S. Spatio-temporal drought analysis in arid and semiarid regions: A case study from Palestine. Arab. J. Sci. Eng. 2012, 38, 2303-2313. [CrossRef]

39. PWA. Status Report of Water Resources in the Occupied State of Palestine; Palestinian Water Authority: Ramallah, Palestine, 2013.

40. Shadeed, S. Up to Date Hydrological Modeling in Arid and Semi-arid Catchment, the Case of Faria Catchment, West Bank, Palestine. Ph.D. Thesis, Faculty of Forest and Environmental Sciences, Albert-Ludwigs-Universität, Freiburg imBreisgau, Germany, 2008.

41. Gould, J.; Nissen-Petersen, E. Rainwater Catchment Systems for Domestic Supply: Design, Construction and Implementation; Intermediate Technology Publications: London, UK, 1999.

42. PMD. Meteorological Database; Palestinian Metrological Department: Ramallah, Palestine, 2019.

43. Al-Houri, Z.M.; Abu-Hadba, O.K.; Hamdan, K.A. The Potential of Roof Top Rain Water Harvesting as a Water Resource in Jordan: Featuring Two Application Case Studies. Int. J. Environ. Chem. Ecol. Geol. Geophys. Eng. 2014, 8, 147-153.

44. Abdulla, F.A.; Al-Shareef, A.W. Roof rainwater harvesting systems for household water supply in Jordan. Desalination 2009, 243, 195-207. [CrossRef]

45. Ghisi, E.; Montibeller, A.; Schmidt, R.W. Potential for potable water savings by using rainwater: An analysis over 62 cities in southern Brazil. Build. Environ. 2006, 41, 204-210. [CrossRef]

46. Hari, D.; Reddy, K.R.; Vikas, K.; Srinivas, N.; Vikas, G. Assessment of rainwater harvesting potential using GIS. IOP Conf. Ser. Mater. Sci. Eng. 2018, 330,1-9. [CrossRef]

47. Liaw, C.-H.; Tsai, Y. Optimum storage volume of rooftop rain water harvesting systems for domestic use. J. Am. Water Resour. Assoc. 2004, 40, 901-912. [CrossRef] 